\title{
Candida thaimueangensis sp. nov., an anamorphic yeast species from estuarine water in a mangrove forest in Thailand
}

Correspondence

Savitree Limtong

fscistl@ku.ac.th

\author{
Savitree Limtong, ${ }^{1}$ Wichien Yongmanitchai, ${ }^{1}$ Hiroko Kawasaki ${ }^{2}$ \\ and Tatsuji Seki ${ }^{2}$
'Department of Microbiology, Faculty of Science, Kasetsart University, 50 Paholyothin Rd, Bangkok 10900, Thailand Osaka 565-0871, Japan \\ ${ }^{2}$ The International Center for Biotechnology, Osaka University, 2-1 Yamada-oka, Suita-City,
}

\begin{abstract}
Four yeast strains (TM1-01 ${ }^{\top}, \mathrm{TM}^{-07}, \mathrm{TM} 3-47$ and TM3-49) were isolated by membrane filtration from estuarine water collected from a mangrove forest in Phang-Nga province, southern Thailand. Analysis of the D1/D2 domains of the large-subunit rDNA sequence revealed that the sequences of the four strains were identical. The closest recognized species in terms of pairwise sequence similarity was Pichia deserticola, but the level of nucleotide substitution (4.8\%) was sufficient to justify the description of a separate species. Phylogenetic analysis demonstrated that the four strains occupy a basal position with respect to Pichia membranifaciens and close relatives. The four strains showed identical phenotypic characteristics, including proliferation by multilateral budding, absence of ascospores, arthrospores and ballistospores and negative reactions for Diazonium blue $\mathrm{B}$ and urease. The major ubiquinone was $\mathrm{Q}-7$. On the basis of the above findings, these four strains were assigned to a single novel species of the genus Candida, for which the name Candida thaimueangensis sp. nov. is proposed. The type strain is TM1-01 ${ }^{\top}\left(=\mathrm{CBS} 10360^{\top}\right.$ $=$ NBRC $101967^{\top}=$ BCC $21229^{\top}$ ).
\end{abstract}

Yeasts of the genus Candida, one of the largest genera in terms of numbers of species, are widely distributed in nature. Species of this genus have been isolated from various sources in terrestrial and aquatic habitats (Butinar et al., 2005; de Almeida, 2005; Pimentel et al., 2005; Rhishipal \& Philip, 1998; Ruivo et al., 2004; Soares et al., 1997; Suh et al., 2004). In Thailand, both basidiomycetous and ascomycetous yeasts are rich in species diversity (Nakase, 2000; Nakase et al., 2001; Jindamorakot et al., 2004). At the time of writing, 10 novel ascomycetous yeast species have been described from Thailand (Nagatsuka et al., 2002; Nakase et al., 2005; Jindamorakot et al., 2004; Limtong et al., 2004, 2005; Sumpradit et al., 2005; Suzuki et al., 1994). Among these, six species belong to the genus Candida: Candida stellimalicola, isolated from star apple (Suzuki et al., 1994), C. easanensis, C. pattaniensis and C. nakhonratchasimensis, isolated from insect frass (Jindamorakot et al., 2004), and $C$. krabiensis and C. sithepensis, isolated from soil (Limtong et al., 2004). Until now there has been no description of novel yeast species isolated from water in a natural ecosystem owing to the lack of studies of yeast diversity in aquatic environments in Thailand.

The GenBank/EMBL/DDBJ accession number for the D1/D2 domain of the LSU rDNA sequence of TM1- $01^{\top}$ is AB264009.
In the course of an investigation of yeasts in aquatic habitats in Thailand, including estuarine water in mangrove forests and seawater, various strains of yeasts were isolated by membrane filtration. In this study we describe four strains obtained from estuarine water in a mangrove forest as representing a novel species of the genus Candida.

Four yeast strains, TM1-01 ${ }^{\mathrm{T}}$, TM1-07, TM3-47 and TM349 , were isolated by membrane filtration of water samples collected from a mangrove forest in Khao Lumpee-Haad Thaimueang National Park, Amphoe Thaimueang, PhangNga province, Thailand. Fifty to two hundred millilitres of water was filtered through $0.8-\mu \mathrm{m}$ pore size membrane filters, which were placed on acidified yeast extract $/$ malt extract (YM) broth $(0.3 \%$ yeast extract, $0.3 \%$ malt extract, $0.5 \%$ peptone, $1 \%$ glucose, adjusted to $\mathrm{pH} 3.7-3.8$ with $1 \mathrm{M} \mathrm{HCl}$ ) supplemented with $0.025 \%$ sodium propionate and $200 \mathrm{mg}$ chloramphenicol $\mathrm{l}^{-1}$, and incubated for 2-3 days at room temperature. Yeast colonies were picked and purified by cross streaking on YM agar.

Methods for DNA isolation, amplification of the D1/D2 domains of the large-subunit (LSU) and small-subunit (SSU) rDNA by PCR and sequencing with the ABI BigDye Terminator Cycle Sequencing kit version 3.1 (Applied Biosystems) by using an ABI PRISM 3100 automated DNA 
sequencer (Applied Biosystems) were as described previously (Limtong et al., 2007). The sequences were compared pairwise by BLAST searches (Altschul et al., 1990) and were aligned with the sequences of related species retrieved from GenBank by using the multiple alignment program CLUSTAL X version 1.81 (Thompson et al., 1997). A phylogenetic tree was constructed from the evolutionary distance data with Kimura's two-parameter correction (Kimura, 1980), by using the neighbour-joining method (Saitou \& Nei, 1987). Confidence in the phylogenetic tree was estimated from bootstrap analysis (1000 replicates) (Felsenstein, 1985). The new strains were characterized morphologically, biochemically and physiologically according to the standard methods described by Yarrow (1998). Assimilation of nitrogen compounds was examined on solid media with starved inocula following the method of Nakase \& Suzuki (1986). Growth at various temperatures was determined by cultivation on yeast extract/peptone/dextrose (YPD) agar ( $1 \%$ yeast extract, $2 \%$ peptone, $2 \%$ glucose and $2 \%$ agar). Ubiquinones were extracted from intact packed cells cultivated in YPD broth on a rotary shaker at $28^{\circ} \mathrm{C}$ for 24-48 $\mathrm{h}$ and purified according to the methods described by Yamada \& Kondo (1973) and Kuraishi et al. (1985). The isoprenologues were identified by HPLC by using a Cosmosil (Waters 5C18) $4.6 \times 250-\mathrm{mm}$ column and methanol/2propanol $(2: 1)$ at $1 \mathrm{ml} \mathrm{min}^{-1}$ as the elution system with spectrophotometric detection (wavelength $275 \mathrm{~nm}$ ).

The sequences of the D1/D2 domains of the LSU rDNA of the four strains were identical. The closest species to the four strains in terms of pairwise sequence similarity was Pichia deserticola, but with $4.8 \%$ nucleotide substitutions (27 nucleotide substitutions in $558 \mathrm{nt}$ ). According to Kurtzman \& Robnett (1998), yeast strains showing nucleotide substitutions of greater than $1 \%$ in the D1/D2 domain of the LSU rDNA are usually representative of different species. The phylogenetic tree based on the sequences of the D1/D2 domains of the LSU rDNA further demonstrated that the four strains are placed at a position distinct from
P. deserticola and other related species in the Pichia membranifaciens clade (Fig. 1). The SSU rDNA sequences of the four new strains were also identical (data not shown). Accordingly, the four new strains are considered to represent a single, novel, phylogenetically distinct species.

The four strains proliferated by multilateral budding (Fig. 2), were negative for Diazonium blue B and urease reactions and had Q-7 as the major ubiquinone, as do other members of the P. membranifaciens clade. They did not produce ascospores on YM agar, $5 \%$ malt extract agar, Fowell's acetate agar or Gorodkowa agar after 5 weeks at $28^{\circ} \mathrm{C}$, and on this basis are assigned to the genus Candida. The name Candida thaimueangensis sp. nov. is proposed to accommodate these new strains.

In practice, Candida thaimueangensis can be distinguished from $P$. deserticola, its closest phylogenetic relative, only on the basis of sequence comparisons, as differences in phenotypic characteristics are minor (Table 1).

\section{Latin diagnosis of Candida thaimueangensis Limtong, Yongmanitchai, Kawasaki et Seki sp. nov.}

In agaro YM post dies 3 ad $28^{\circ} \mathrm{C}$ cellulae globosae, ellipsoideae aut elongatae $(2.2-5.2 \times 2.6-6.5 \mu \mathrm{m})$, singulae aut binae, per gemmationem multipolarem reproducentes. Cultura butyrosa, cremea, seminitidae, glabra, margine glabra. In agaro farinae Zea mays post dies 7 ad $28^{\circ} \mathrm{C}$ et agaro YM post dies 21 ad $25^{\circ} \mathrm{C}$ pseudohyphae formantur, hyphae non formantur. Ascosporae non formantur. In medio liquido $\mathrm{YM}$ post dies 3 ad $28{ }^{\circ} \mathrm{C}$, repens pellicula formatur. Fermentatio nulla. Glucosum, D-xylosum (lente), glycerolum, acidum DL-lacticum, acidum succinicum et ethanolum assimilantur at non D-galactosum, L-sorbosum, D-ribosum, L-arabinosum, D-arabinosum, L-rhamnosum, sucrosum, maltosum, trehalosum, cellobiosum, melibiosum, lactosum, raffinosum, melezitosum, inulinum, erythritolum, D-mannitolum, galactitolum,

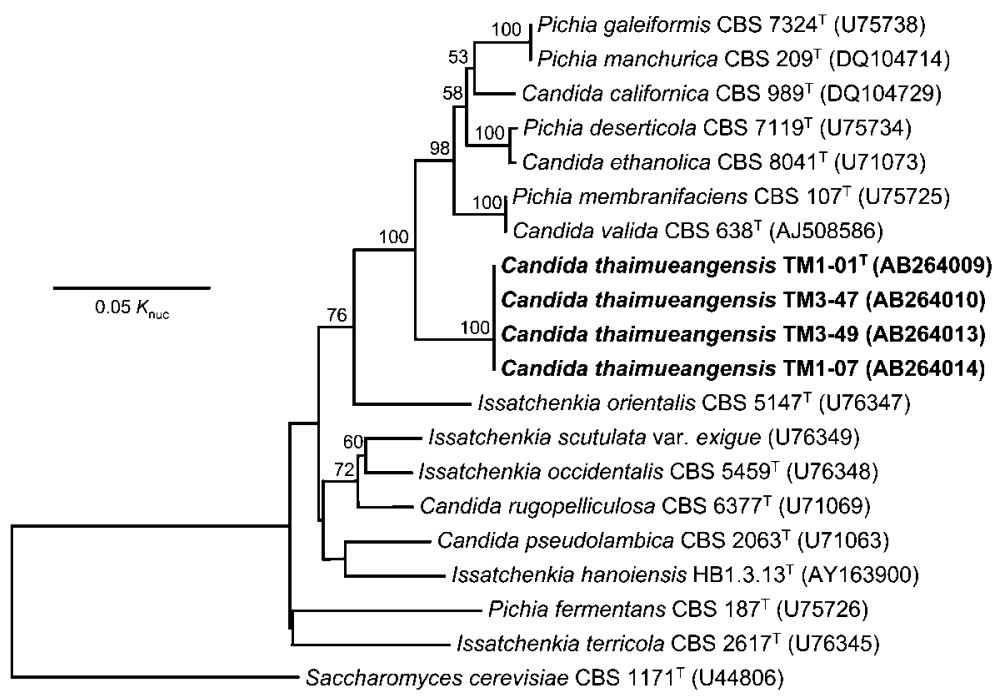

Fig. 1. Phylogenetic tree based on the D1/ D2 domains of the LSU rDNA, showing positions of the four new strains with respect to closely related species. The phylogenetic tree was constructed from evolutionary distance data with Kimura's two-parameter correction (Kimura, 1980), by using the neighbour-joining method. Numbers indicate percentages of bootstrap support, derived from 1000 samples. 

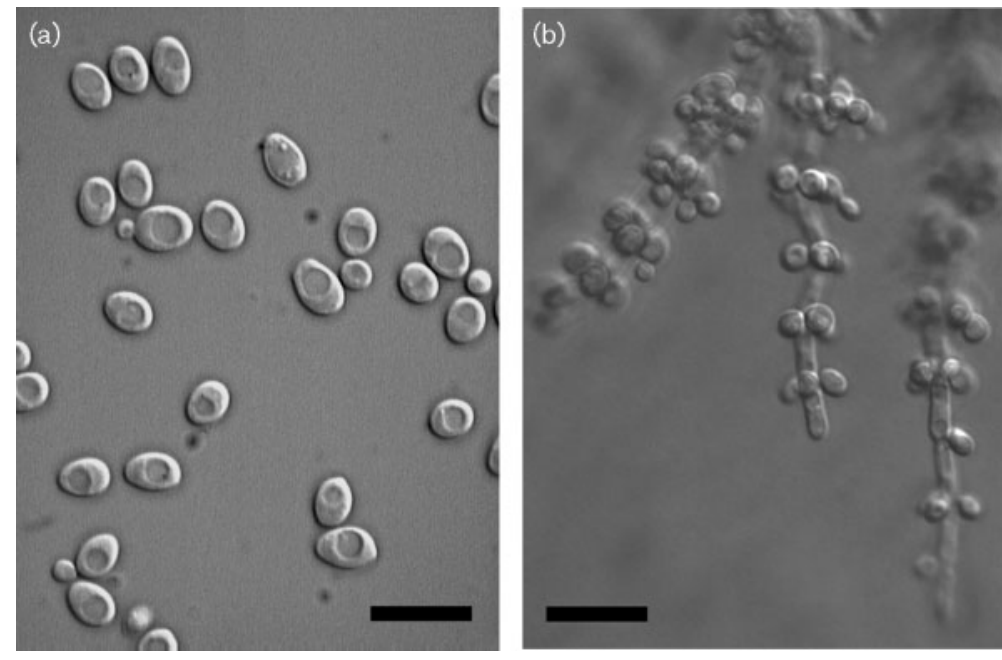

Fig. 2. Cells of strain $\mathrm{TM} 1-01^{\top}$. (a) Vegetative cells grown on YM agar after 3 days at $28^{\circ} \mathrm{C}$ and (b) pseudohyphae produced on cornmeal agar after 7 days at $28^{\circ} \mathrm{C}$. Bars, $10 \mu \mathrm{m}$.

inositolum, glucono- $\delta$-lactonum, acidum 2-ketogluconicum, acidum D-gluconicum, acidum D-glucuronicum, acidum D-galacturonicum, acidum citricum nec methanolum. Ethylaminum, L-lysinum et cadaverinum assimilatur at non nitrium nitricum nec nitrium nitrosum. Ad crescentiam vitamina externa non necessaria. Crescit in temperatura $37^{\circ} \mathrm{C}$ at non in $40{ }^{\circ} \mathrm{C}$. Crescit (exigue) in $50 \%$ glucosum. Non crescit in $0.01 \%$ cycloheximido, $60 \%$ glucosum nec $10 \%$ natrii chloridum $/ 5 \%$ glucosum. Amylum non formatur. Ureum non hydrolysatur. Diazonium caeruleum B non respondens. Ubiquinonum majus: Q-7.

Typus stirpis TM1-01 $1^{\mathrm{T}}\left(=\mathrm{CBS} 10360^{\mathrm{T}}=\mathrm{NBRC} 101967^{\mathrm{T}}=\right.$ BCC $21229^{\mathrm{T}}$ ) isolatus aqua, Phang-Nga Provincia, Thailandia, conservatur in collectionibus culturarum quas Centraalbureau voor Schimmelcultures (Utrecht, The Netherlands), NITE Biological Resource Center (Chiba, Japan) et BIOTEC Culture Collection, National Central for Genetic Engineering and Biotechnology, Thailand (Pathumthani, Thailand) deposita est.

\section{Description of Candida thaimueangensis Limtong, Yongmanitchai, Kawasaki \& Seki sp. nov.}

Candida thaimueangensis (thai.mueang.en'sis. N.L. fem. adj. thaimueangensis referring to Thaimueang, Thailand, where the four strains were isolated).

After growth on YM agar for 3 days at $28^{\circ} \mathrm{C}$, cells are spheroidal, ellipsoidal to elongate $(2.2-5.2 \times 2.6-6.5 \mu \mathrm{m})$ and occur singly, in pairs or in short chains (Fig. 2). Colonies are butyrous, cream-coloured, semi-glistening and raised, with a smooth surface and have an entire margin. Budding is multilateral. After 7 days in Dalmau plate cultures on cornmeal agar at $28{ }^{\circ} \mathrm{C}$ and $\mathrm{YM}$ agar at $25^{\circ} \mathrm{C}$, pseudohyphae are formed but true hyphae are not formed. No arthrospores are produced. No ascospores are produced from individual strains on YM agar, $5 \%$ malt extract agar, Fowell's acetate agar or Gorodkowa agar after 5 weeks at $28^{\circ} \mathrm{C}$. In YM broth, after 3 days at $28^{\circ} \mathrm{C}$, creeping pellicles and floating islets are present. A pellicle is not present during growth on the surface of assimilation medium. The major ubiquinone is Q-7. Phenotypic characteristics of the species are given in Table 1.

Table 1. Differential phenotypic characteristics between strain $\mathrm{TM} 1-01^{\top}$ and Pichia deserticola

Strains TM1-01 ${ }^{\mathrm{T}}$, TM1-07, TM3-47 and TM3-49 gave identical results. All strains were negative for fermentation. D-Glucose, glycerol, ethanol, ethylamine hydrochloride, L-lysine hydrochloride and cadaverine were assimilated by all strains, but D-galactose, Lsorbose, L-rhamnose, D-ribose, L-arabinose, D-arabinose, sucrose, maltose, trehalose, cellobiose, melibiose, lactose, raffinose, melezitose, inulin, erythritol, mannitol, galactitol, myo-inositol, 2-ketogluconic acid, D-gluconic acid, D-glucuronic acid, D-galacturonic acid, citric acid, methanol, potassium nitrate and sodium nitrite were not. All strains grew at $25,30,35$ and $37^{\circ} \mathrm{C}$. Growth in vitamin-free medium was negative. Growth on medium containing $0.01 \%$ cycloheximide, $60 \%$ glucose and $10 \%(\mathrm{w} / \mathrm{v})$ sodium chloride $/ 5 \%(\mathrm{w} / \mathrm{v})$ glucose was negative in all cases. Production of amyloid compound was negative in all cases. Diazonium blue $\mathrm{B}$ and urease reactions were negative in all cases. Symbols: + , positive; - negative; D, delayed positive; s, slow; W, weak.

\begin{tabular}{|lcc|}
\hline Characteristic & Strain TM1-01 $^{\mathbf{T}}$ & $\boldsymbol{P . ~ d e s e r t i c o l a ~}^{-}$ \\
\hline Ascospore formation & - & + \\
Assimilation of: & & - \\
D-Xylose & $\mathrm{S}$ & $\mathrm{D},-$ \\
D-Glucono-1,5-lactone & - &,$+ \mathrm{W}$ \\
DL-Lactate & + & $\mathrm{W},-$ \\
Succinic acid & + & \\
Growth: & &,+- \\
At $40{ }^{\circ} \mathrm{C}$ & - &,$+ \mathrm{D}$ \\
With $50 \%$ glucose & $\mathrm{W}$ & \\
\hline
\end{tabular}


The type strain, TM1-01 ${ }^{\mathrm{T}} \quad\left(=\mathrm{CBS} \quad 10360^{\mathrm{T}}=\mathrm{NBRC}\right.$ $101967^{\mathrm{T}}=$ BCC $21229^{\mathrm{T}}$ ), was isolated from water in a mangrove forest in Kho Lumpee-Haad Thaimueang National Park, Phang-Nga province, Thailand.

\section{Acknowledgements}

We are grateful to IC Biotech, Osaka University, Japan, the National Research Council, Thailand (NRCT), and Japan Science and Technology Agency (JST) for financial and technical support. Many thanks go to Dr Sasitorn Jindamorakot, Ms Chutima Sringiew, Ms Suthida Tuntigumton and Ms Somji Am-in for experimental help.

\section{References}

Altschul, S. F., Gish, W., Miller, W., Meyers, E. W. \& Lipman, D. J. (1990). Basic local alignment search tool. J Mol Biol 215, 403-410.

Butinar, L., Santos, S., Spencer-Martins, I., Oren, A. \& GundeCimerma, N. (2005). Yeast diversity in hypersaline habitats. FEMS Microbiol Lett 244, 229-234.

de Almeida, J. M. G. C. F. (2005). Yeast community survey in the Tagus estuary. FEMS Microbiol Ecol 53, 295-303.

Felsenstein, J. (1985). Confidence limits on phylogenies: an approach using the bootstrap. Evolution 39, 783-791.

Jindamorakot, S., Am-in, S., Thuy, T. T., Duy, N. D., Kawasaki, H., Potacharoen, W., Limtong, S., Tanticharoen, M. \& Nakase, T. (2004). Candida easanensis sp. nov., Candida pattaniensis sp. nov. and Candida nakhonratchasimensis sp. nov., three new species of yeasts isolated from insects frass in Thailand. J Gen Appl Microbiol 50, 261-269.

Kimura, M. (1980). A simple method for estimating evolutionary rates of base substitutions through comparative studies of nucleotide sequences. J Mol Evol 16, 111-120.

Kuraishi, H., Katayama-Fujimura, Y., Sugiyama, J. \& Yokoyama, T. (1985). Ubiquinone systems in fungi I. Distribution of ubiquinones in the major families of ascomycetes, basidiomycetes, and deuteromycetes, and their taxonomic implications. Trans Mycol Soc Jpn 26, 383-395.

Kurtzman, C. P. \& Robnett, C. J. (1998). Identification and phylogeny of ascomycetous yeasts from analysis of nuclear largesubunit (26S) ribosomal DNA partial sequences. Antonie van Leeuwenhoek 73, 331-371.

Limtong, S., Srisuk, N., Yongmanitchai, W., Kawasaki, H., Yurimoto, H., Nakase, T. \& Kato, N. (2004). Three new thermotolerant methylotrophic yeasts, Candida krabiensis sp. nov., Candida sithepensis sp. nov., and Pichia siamensis sp. nov. isolated in Thailand. J Gen Appl Microbiol 50, 119-127.

Limtong, S., Srisuk, N., Yongmanitchai, W., Yurimoto, H., Nakase, T. \& Kato, N. (2005). Pichia thermomethanolica sp. nov., a novel thermotolerant, methylotrophic yeast isolated in Thailand. Int J Syst Evol Microbiol 55, 2225-2229.

Limtong, S., Yongmanitchai, W., Tun, M. M., Kawasaki, H. \& Seki, T. (2007). Kazachstania siamensis sp. nov., an ascomycetous yeast species from forest soil in Thailand. Int J Syst Evol Microbiol 57, 419-422.
Nagatsuka, Y., Kawasaki, H., Limtong, S., Mikata, K. \& Seki, T. (2002). Citeromyces siamensis sp. nov., a novel halotolerant yeast isolated in Thailand. Int J Syst Evol Microbiol 52, 2315-2319.

Nakase, T. (2000). Expanding world of ballistosporous yeasts: distribution in the phyllosphere, systematics and phylogeny. J Gen Appl Microbiol 46, 189-216.

Nakase, T. \& Suzuki, M. (1986). Bullera megalospora, a new species of yeast forming larger ballistospores isolated from dead leaves of Oryza sativa, Miscanthus sinensis and Sasa sp. in Japan. J Gen Appl Microbiol 32, 225-240.

Nakase, T., Takashima, M., Itoh, M., Fungsin, B., Potacharoen, W., Atthasampunna, P. \& Komagata, K. (2001). Ballistoconidiumforming yeasts found in the phyllosphere of Thailand. Microbiol Cult Coll 17, 23-33.

Nakase, T., Jindamorakot, S., Am-in, S., Kawasaki, H., Potacharoen, W. \& Tanticharoen, M. (2005). Pichia nongkratonensis sp. nov., a new species of ascomycetous yeast isolated from insect frass collected in Thailand. Mycoscience 46, 192-195.

Pimentel, M. R. C., Antonini, Y., Martins, R. P., Lachance, M.-A. \& Rosa, C. A. (2005). Candida riodocensis and Candida cellae, two new yeast species from the Starmerella clade associated with solitary bees in the Atlantic rain forest of Brazil. FEMS Yeast Res 5, 875-879.

Rhishipal, R. \& Philip, R. (1998). Selection of marine yeasts for the generation of single cell protein from prawn-shell waste. Bioresour Technol 65, 255-256.

Ruivo, C. C. C., Lachance, M.-A., Bacci, M., Jr, Carreiro, S. C., Rosa, C. A. \& Pagnocca, F. C. (2004). Candida leandrae sp. nov., an asexual ascomycetous yeast species isolated from tropical plants. Int J Syst Evol Microbiol 54, 2405-2408.

Saitou, N. \& Nei, M. (1987). The neighbor-joining method: a new method for reconstructing phylogenetic trees. Mol Biol Evol 4, 406-425.

Soares, C. A. G., Maury, M., Pagnocca, F. C., Araujo, F. V., Mendonca-Hagler, L. C. \& Hagler, A. N. (1997). Ascomycetous yeasts from tropical intertidal dark mud of southeast Brazilian estuaries. J Gen Appl Microbiol 43, 265-272.

Suh, S.-O., McHugh, J. V. \& Blackwell, M. (2004). Expansion of the Candida tanzawaensis yeast clade: 16 Candida species from basidiocarp-feeding beetles. Int J Syst Evol Microbiol 54, 2409-2429.

Sumpradit, T., Limtong, S., Yongmanitchai, W., Kawasaki, H. \& Seki, T. (2005). Tetrapisispora namnaonensis sp. nov., a novel ascomycetous yeast species isolated from forest soil of Nam Nao National Park, Thailand. Int J Syst Evol Microbiol 55, 1735-1738.

Suzuki, M., Nakase, T. \& Komagata, K. (1994). Candida stellimalicola, a new species of anamorphic yeast isolated from star apple in Thailand. J Gen Appl Microbiol 40, 115-121.

Thompson, J. D., Gibson, T. J., Plewniak, F., Jeanmougin, F. \& Higgins, D. G. (1997). The CLUSTAL_X windows interface: flexible strategies for multiple sequence alignment aided by quality analysis tool. Nucleic Acids Res 25, 4876-4882.

Yamada, Y. \& Kondo, K. (1973). Coenzyme Q system in the classification of the yeast genera Rhodotorula and Cryptococcus and the yeast-like genera Sporobolomyces and Rhodosporidium. J Gen Appl Microbiol 19, 59-77.

Yarrow, D. (1998). Methods for the isolation, maintenance and identification of yeasts. In The Yeasts, a Taxonomic Study, 4th edn, pp. 77-100. Edited by C. P. Kurtzman \& J. W. Fell. Amsterdam: Elsevier. 